\title{
FOREWORD; OR READING WITHIN THE GUTTER
}

DEREK PARKER ROYAL

A

LTHOUGH NOT SOLELY an image-based medium, comics get most of their power through their visuals, the ways in which authors construct the representations we see on the page or computer screen. Such art should not be taken lightly, for as history literally illustrates, the attitudes and prejudices of a culture can be greatly shaped by its caricatures, cartoons, and other forms of manipulated iconography. This is especially the case when it comes to the representations of minority populations, groups and individuals who live on-or who have been relegated to - the fringes of a society and whose place has historically been dictated by a more dominant culture. This is what Will Eisner, one of the pioneers in American comics, alludes to in Graphic Storytelling and Visual Narrative (1996) when he discusses the inescapable uses of stereotypes in graphic narrative. Comics, by necessity, employ stereotypes as a kind of shorthand to communicate quickly and succinctly. This being the case, it is up to the comic's artist to tell her or his story as effectively as possible without slipping into the trap, even inadvertently, of inaccurate and even harmful representations. To paraphrase Stan Lee, with great visual power must also come great responsibility.

The cultural potential underlying comics is all too apparent, and recent events around the world have underscored the stakes involved. Witness, for example, the violent outcry in 2005 over the Muhammad caricatures that appeared in the Danish newspaper Jyllands-Posten, the official charges of racism leveled against 
Hergés Tintin in the Congo made in both the United Kingdom and Belgium during 2007, or the more recent controversy surrounding Sean Delonas's cartooned allusions to President Barack Obama in the New York Post. Because they utilize picture texts to guide our understanding of narrative, comics can have a more direct effect than that dictated by prose, eliciting a reaction that takes relatively little time to process. And given its reliance on symbols and iconography, comic art speaks in a language that is accessible to a wide audience, transcending many of the national, cultural, and linguistic boundaries imposed by other media and giving it a reach that is as democratic as it is immediate. Comics artists who represent marginalized communities, or "the Other," do so under potentially liberating, yet nonetheless volatile, contexts.

Frederick Aldama understands this dilemma. He has spent much of his career exploring the crossroads of narrative and ethnicity, and he has also cast his gaze upon the manifestations of race in our popular culture. In works such as Brown on Brown (2005) and Spilling the Beans in Chicanolandia (2006), Aldama has looked at how visual media such as film and graphic narrative have represented the marginalized subject. His appreciation of comics is especially evident in the more recent Your Brain on Latino Comics (2009), a text exploring the kinds of visual dynamics involved in ethnoracial narrative. His present volume, Multicultural Comics: From Zap to Blue Beetle, furthers that understanding and does so by bringing together diverse voices within comics studies. This edited collection is a welcome addition to the ever-growing scholarship on comic books, graphic novels, and graphic narrative in all of its forms. The various essays that follow encompass a wide variety of readings from many different perspectives. Indeed, one of the book's greatest strengths is its willingness to enlarge our understanding of "multicultural" (a term that is usually linked to U.S.-based culture) and expand its scope beyond the confines of comics produced in or related to American ethnicity. Not only does Aldama's collection serve as a useful introduction to the topics of race, ethnicity, gender, and nation within graphic narrative-a field of study with a thin history-but it also stands as a valuable resource in two other fields: the study of comics in general, and criticism surrounding multicultural narrative as a whole, regardless of the medium employed.

Unlike contributors to several other recent scholarly studies of graphic narrative, the authors of this volume do not limit themselves to "literary," or nongeneric, comics - that is, the kind of comics that have come to define "the graphic novel" for so many readers. Standing alongside studies of Adrian Tomine, Robert Crumb, and Jessica Abel you will find discussions of Marv Wolfman and Gene Colan's The Tomb of Dracula, Grant Morrison's work for DC Comics, and the recent manifestations of Batwoman. What is more, several contribu- 
tors focus on comics that fly under the radar of most studies. The essays on Anishinaabe-related comics, DJ Spooky's visual remix of classic film, and the role of graphic novels in India not only contest our conventional understanding of graphic narrative, but give Aldama's collection a truly democratic feel.

The politics of multicultural representations within comics is a rich field of inquiry, one that is just waiting to be tapped. In the pages that follow, Frederick Aldama and his compatriots demonstrate how a medium long regarded as incidental and disposable can take on some of our culture's most challenging questions. If, as Will Eisner believed, stereotypes are an unavoidable necessity of comic art, then the essays in this collection help us to revisualize those "gutter" spaces that lie outside of our more privileged cultural frames. 
THIS PAGE INTENTIONALLY LEFT BLANK 
MULTLCULTURAL 
THIS PAGE INTENTIONALLY LEFT BLANK 